\title{
ANALISIS DUKUNGAN KELUARGA DALAM KEMANDIRIAN LANSIA DI DESA PAYUNGSARI KE CAMATAN PEDES KABUPATEN KARAWANG
}

\author{
Annisa Al Munawaroh 1,a), Shinta Doriza ${ }^{1, b)}$, Hamiyati $\left.1, c\right)$ \\ b)shintadoriza75@gmail.com, c)hamiyati32@yahoo.com \\ 1Program Studi Pendidikan Kesejahteraan Keluarga \\ Fakultas Teknik, Universitas Negeri J akarta \\ J In. Rawamangun Muka, J akarta Timur. 13220
}

\begin{abstract}
Abstrak
Lansia (lanjut usia) adalah seseorang yang karena usianya mengalami perubahan biologis, fisik, kejiwaan dan sosial. Ukuran kemandirian lansia dapat dilihat dengan cara lansia melakukan aktifitasnya sendiri tanpa bantuan dari orang lain. Dukungan keluarga diperlukan untuk dapat menjadi fasilitator yang menjembatani antara lansia dengan lingkungan dan masyarakat. Penelitian ini bertujuan untuk mengetahui bagaimana dukungan keluarga dalam kemandirian lansia di desa Payungsari kecamatan Pedes kabupaten Karawang. Penelitian tentang "Analisis Dukungan Keluarga dalam Kemandirian Lansia" ini menggunakan pendekatan kualitatif, yaitu penelitian dengan menggunakan fakta dan interpretasi yang sesuai. Dalam penelitian ini, peneliti mencoba untuk mengetahui dan mengerti bagaimana kondisi lansia, latar belakang orangtua yang tinggal dengan keluarga mereka, dan bagaimana keluarga mendukung lansia dapat mandiri di lanjut usia. Hasil penelitian ini menunjukkan bahwa komponen yang paling dominan dari dukungan keluarga adalah dukungan nyata, dukungan penghargaan dan dukungan emosional. Penelitian ini menemukan bahwa satu dari delapan responden yang mendapatkan dukungan keluarga, dan satu responden yang mendapatkan empat komponen dari dukungan keluarga.
\end{abstract}

Kata Kunci : Dukungan keluarga, kemandirian lansia

\section{Analysis of Family Support in EIderly Independence at Payungsari Village Pedes Karawang}

\begin{abstract}
Elderly is a person who has biological, physical, psychological and social changes because of age. Criteria of the elderly independence can be viewed by way of the elderly do their own activities without help from others. Family support is needed to be able to become a facilitator that bridges between the elderly with the environment and society. This study aims to know how family support in the elderly independence in Payungsari village of $P$ edes Karawang districts The research used a qualitative approach, that is a research about the fact with appropriate interpretation. In this study, researcher tried to find out and understand how the condition of the elderly, the background of elderly who live with their families, and how families can support independence of the elderly. The results of this study showed that the most dominant component of family support was obvious support, appreciation support and emotional support. The research found that 1 of 8 respondents who get a whole family support and 1 respondent who get 4 components of family support.
\end{abstract}

Keywords: Family Support, E Iderly Independence. 


\section{PENDAHULUAN}

Lansia (lanjut usia) adalah seseorang yang Karena usianya mengalami perubahan biologis, fisik, kejiwaan dan sosial (UU No.23 Tahun 1992 tentang Kesehatan). Lansia adalah seseorang yang telah mencapai usia 60 tahun keatas, terdiri dari lansia usia potensial yaitu lansia yang masih mampu melakukan pekerjaan dan kegiatan yang dapat menghasilkan barang atau jasa, dan lansia tak potensial yaitu lansia yang tidak berdaya mencari nafkah sehingga hidupnya tergantung pada bantuan orang lain (Undang-Undang Republik Indonesia Nomor 13 Tahun 1998).

Pada usia lanjut terjadi penurunan kondisi fisik/biologis, kondisi psikologis serta perubahan kondisi sosial. Para usia lanjut bahkan masyarakat menganggap seakan-akan tugasnya sudah selesai, mereka berhenti bekerja dan semakin mengundurkan diri dari pergaulan masyarakat yang merupakan salah satu ciri fase ini. Dalam fase ini ciri usia lanjut biasanya merenungkan hakikat hidupnya dengan lebih intensif serta mencoba mendekatkan dirinya pada tuhan (Tamher, 2009).

Ukuran kemandirian lansia dapat dilihat dengan cara lansia melakukan aktifitasnya sendiri tanpa bantuan dari orang lain. Lanjut usia potensial adalah lanjut usia yang masih mampu melakukan pekerjaan dan atau kegiatan yang dapat (Indriana, 2012). menghasilkan barang dan atau jasa (Indriana, 2012).

Kesejahteraan penduduk usia lanjut yang karena kondisi fisik dan/atau mentalnya tidak memungkinkan lagi untuk berperan dalam pembangunan maka, lansia perlu mendapat perhatian khusus dari pemerintah dan masyarakat (Maryam, 2009).

Mengenai pola mortalitas menunjukkan bahwa lansia yang tinggal bersama keluarga lebih mungkin untuk bertahan hidup dan mempertahankan kemandirian mereka di bandingkan mereka yang hidup sendiri.

Dukungan keluarga adalah sebagai suatu proses hubungan antara keluarga dengan lingkungan (Setiadi, 2008). Menurut Smet (1994) dalam Christine (2010). Dukungan keluarga didefinisikan sebagai informasi verbal atau nonverbal, saran, bantuan yang nyata atau tingkah laku yang diberikan oleh orang-orang yang akrab dengan subjek di dalam lingkungannya atau yang berupa kehadiran dan hal-hal yang dapat memberikan keuntungan emosional dan berpengaruh pada tingkah laku penerimanya. Dalam hal ini orang yang merasa memperoleh dukungan secara emosional merasa lega karena diperhatikan, mendapat saran atau kesan yang menyenangkan pada dirinya.

Komponen-komponen dukungan keluarga, terdiri dari: (1) dukungan penghargaan, (2) dukungan nyata, (3) dukungan informasi, (4) dukungan emosional (Sarafino dalam Christine, 2010), dan (5) dukungan sosial (Friedman,2002).

Pertama, dukungan pengharapan meliputi pertolongan pada individu untuk memahami kejadian depres dengan baik dan juga sumber depresi dan strategi koping yang dapat digunakan dalam menghadapi stressor. Dukungan ini juga merupakan dukungan yang terjadi bila ada ekspresi penilaian yang positif terhadap individu. Individu mempunyai seseorang yang dapat diajak bicara tentang masalah mereka, terjadi melalui ekspresi pengaharapan positif individu kepada individu lain, penyemangat, persetujuan terhadap ide-ide atau perasaan seseorang dan perbandingan positif seseorang dengan orang lain, misalnya orang yang kurang mampu. Dukungan keluarga dapat membantu meningkatka strategi koping individu dengan strategi-strategi alternatif berdasarkan pengalaman yang berfokus pada aspek-aspek yang positif.

Kedua, dukungan ini meliputi penyediaan dukungan jasmaniah seperti pelayanan, bantuan finansial dan material berupa bantuan nyata (instrumental support material support), suatu kondisi dimana benda atau jasa akan membantu memecahkan masalah praktis, termasuk di dalamnya bantuan langsung, seperti saat seseorang memberi atau meminjamkan uang, membantu pekerjaan sehari-hari, menyampaikan pesan, menyediakan transportasi, menjaga dan merawat saat sakit ataupun mengalami depresi yang dapat membantu memecahkan masalah. Dukungan nyata paling efektif bila dihargai oleh individu dan mengurangi depresi individu. Pada dukungan nyata keluarga sebagai sumber untuk mencapai tujuan praktis dan tujuan nyata. 
Ketiga, dukungan informasi meliputi jaringan komunikasi dan tanggung jawab bersama, termasuk di dalamnya memberikan solusi dari masalah, memberikan nasehat, pengarahan, saran, atau umpan balik tentang apa yang dilakukan oleh seseorang. Keluarga dapat menyediakan informasi dengan menyarankan tentang dokter, terapi yang baik bagi dirinya, dan tindakan spesifik bagi individu untuk melawan stressor. Individu yang mengalami depresi dapat keluar dari masalahnya dan memecahkan masalahnya dengan dukungan dari keluarga dengan menyediakan feedback. Pada dukungan informasi ini keluarga sebagai penghimpun informasi dan pemberi informasi.

Keempat selama depresi berlangsung, individu sering menderita secara emosional, sedih, cemas, dan kehilangan harga diri. Jika depresi mengurangi perasaan seseorang akan hal dimiliki dan dicintai. Dukungan emosional memberikan individu perasaan nyaman, merasa dicintai saat mengalami depresi, bantuan dalam bentuk semangat, empati, rasa percaya, perhatian sehingga individu yang menerimanya merasa berharga. Pada dukungan emosional ini keluarga menyediakan tempat istirahat dan memberikan semangat. Aspek-aspek dari dukungan emosional meliputi dukungan yang diwujudkan dalam bentuk afeksi, adanya kepercayaan, perhatian, mendengarkan dan didengarkan. Dukungan emosional memberikan individu perasaan nyaman, merasa dicintai saat mengalami depresi, bantuan dalam bentuk semangat, empati, rasa percaya, perhatian sehingga individu yang menerimanya merasa berharga.

Kelima, dukungan sosial keluarga mengacu kepada dukungan sosial yang dipandang oleh keluarga sebagai sesuatu yang dapat diakses atau diadakan untuk keluarga (dukungan sosial bisa atau tidak digunakan, tetapi anggota keluarga memandang bahwa orang yang bersifat mendukung selalu siap memberikan pertolongan dan bantuan jika diperlukan). Dukungan sosial keluarga dapat berupa dukungan sosial kelurga internal, seperti dukungan dari suami atau istri serta dukungan dari saudara kandung atau dukungan sosial keluarga eksternal.

Mengenai hal ini mengingat pentingnya peranan keluarga,maka keluarga mesti lebih kuat lagi dalam pelaksanaan tugas keluarga terutama terkait dengan lansia. Salah satu tugas keluarga adalah keluarga harus mampu mengenal masalah-masalah yang terjadi pada lansia. Kemampuan mengenal masalah ini membantu, keluarga, menghadapi masalah perilaku lansia dalam menjalankan aktivitasnya. Keluarga hendaknya terus memberikan dukungan kepada anggota keluarga dan lansia. Dukungan yang diberikan bukan hanya motivasi tapi dukungan lain juga harus diberikan. Selain itu, keluarga juga hendaknya dapat menjadi fasilitator yang menjembatani antara lansia dengan lingkungan dan masyarakat.

Data yang diperoleh dari kantor Balai Desa Payungsari jumlah lansi pada tahun 2015 sebanyak 94 lansia: 54 tinggal dengan keluarga, 40 tinggal sendiri. Alasan mengambil lokasi ini karena desa tersebut berdekatan dengan pesisir yang mana peneliti menganggap bahwa lansia di lokasi tersebut sangat membutuhkan perhatian dibanding dengan lokasi yang berada di kota dan lain sebagainya. Hasil studi pendahuluan yang telah dilakukan peneliti di Dusun Pedes 1 Desa Payungsari Kecamatan Pedes Kabupaten Karawang, didapatkan dari 20 lansia yang tinggal dengan keluarga, sebanyak 12 orang tidak mendapat dukungan keluarga secara optimal dan 9 orang mandiri artinya lansia tersebut masih bisa melakukan aktivitasnya tanpa membutuhkan bantuan dari orang lain, 6 orang ketergantungan ringan artinya lansia tersebut dapat melakukan aktivitasnya sendiri tetapi ketika ia tidak bisa melakukannya maka membutuhkan bantuan orang lain namun arang, 5 orang ketergantungan sedang artinya lansia tersebut hanya aktivitas tertentu saja yang membutuhkan bantuan orang lain, dan 1 orang ketergantungan total artinya lansia sangat membutuhkan bantuan orang lain dalam berbagai aktivitas.

Berdasarkan penjelasan di atas dapat ditarik kesimpulan, bahwa peneliti tertarik untuk menganalisis dukungan keluarga dalam kemandirian lansia dikarenakan jumlah lansia di Desa Payungsari Kecamatan Pedes Kabupaten Karawang merupakan lokasi yang jumlah lansianya tertinggi dibandingkan dengan jumlah lansia di desa yang lain yang berada di Kecamatan Pedes. Sehingga yang menjadi fokus dan kebaharuan dalam penelitian yang diteliti adalah bentuk dukungan keluarga yang seperti apa yang paling dominan dalam kemandirian lansia di Desa Payungsari Kecamatan Pedes Kabupaten Karawang.

Jurnal Kesejahteraan Keluarga dan Pendidikan [JKKP] Vol.03 No.02 doi.org/10.21009/JKKP.032.01 


\section{METODOLOGI PENELITIAN}

Penelitian tentang "Analisis Dukungan Keluarga dalam Kemandirian Lansia di Desa Payungsari Kecamatan Pedes Kabupaten Karawang", pendekatan penelitian yang digunakan adalah pendekatan kualitatif, yaitu sebuah pencarian fakta dengan interprestasi yang tepat. Hal ini dilakukan dengan alasan bahwa suatu fenomena atau peristiwa tertentu akan lebih memiliki arti dan makna jika diuraikan dengan kata-kata daripada menggunakan angka. Menurut Moleong (2007) menjelaskan bahwa penelitian kualitatif adalah penelitian yang bermaksud untuk memahami fenomena tentang apa yang dialami oleh subjek pelitian misalnya perilaku, presepsi, motivasi, tidakan, dan lain-lain.

Pada penelitian ini peneliti berusaha untuk menggali dan mengetahui mengena sisituasi lansia, latar belakang lansia baik yang tinggal bersama keluarga, lalu bagaimana bentuk dungan keluarga pada lansia sehingga berpengaruh dalam kemandirian lansia. Karena kondisi diatas merupakan suatu kasus yang perlu diungkap secara mendalam. Dengan demikian peneliti memutuskan untuk menggunakan penelitian kualitatif dengan metode penelitian deskriptif.

Pada penelitian kualitatif, teknik sampling yang digunakan purposive sampling dan snowball sampling. Data yang digunakan dalam penelitian ini adalah hasil pengamatan terhadap analisis dukungan keluarga dalam kemandirian lansia yang terlihat dan signifikan bagi lansia yang tinggal bersama keluarga. Sebagai komponen penting penelitian, sumber data memiliki peran penting. Pada penelitian ini, sumber data daripenelitianini adalah lansia yang berusia 60-65 tahun.

\section{HASIL DAN PEMBAHASAN}

\section{Deskripsi Responden Penelitian}

\section{Profil Lansia}

Penelitian tentang "Analisis Dukungan Keluarga dalam Kemandirian Lansia di Desa Payungsari Kecamatan Pedes Kabupaten Karawang" ini dilakukan di Desa Payungsari Kecamatan Pedes Kabupaten Karawang. Desa Payungsari ini terletak sekitar $45 \mathrm{~km}$ dari Kota Karawang yang kira-kira bisa memakan waktu kurang lebih 1 jam untuk sampai lokasi. Subjek penelitian ini yaitu lansia yang berusia 60-65 tahun. Pada saat ini lansia yang berusia 60-65 tahun yang tinggal di Desa Payungsari terdapat 282 orang. Tak sedikit lansia di Desa Payungsari yang tinggal bersama keluarga, maksud dari tinggal bersama keluarga adalah lansia yang tinggal serumah dengan anak yang sudah berumah tangga atau dengan keluarga yang lain.

Berdasarkan hasil penelitian yang dilakukan peneliti melalui wawancara secara mendalam kepada setiap lansia ditemukan beberapa komponen dukungan keluarga dalam kemandirian lansia, yaitu sebagai berikut:

\section{Dukungan Keluarga}

Ketika sesorang sudah menjadi lansia maka lansia tersebut akan menjadi sensitif dan merasa ingin dianggap oleh lingkungannya, apalagi oleh keluarganya sendiri. Lansia adalah fase dimana manusia sudah mulai depresi, stress dan banyak pikiran. Oleh karena itu, lansia membutuhkan keberadaan anggota keluarga untuk memberikan semangat atas apa yang dialaminya. Dukungan adalah bentuk positif yang diberikan seseorang kepada seseorang yang lain. Sedangkan nyata adalah segala sesuatu yang benar adanya. Jadi, dukungan nyata adalah sesuatu yang positif yang diberikan oleh seseorang dalam bentuk yang dapat terlihat dan dapat dirasakan oleh orang yang dituju. Dalam hal ini, dukungan nyata yang diberikan keluarga untuk lansia yang tinggal bersama dengan anggota keluarga. Manusia adalah makhluk sosial yang membutuhkan keberadaan orang lain dalam kehiupannya, begitupu lanisa. Lanisa membutuhkan keberadaan orang lain dalam menjalani kehidupannya yang memasuki usia yang penuh dengan permasalahan dan krisis, 
termasuk di dalamnya adalah dukungan sosial dari keluarga. Dukungan sosial yang diberikan keluarga diharapkan oleh lansia supaya keadaan menjadi lebih baik. Keluarga merupakan tempat pelepas lelah setelah seseorang sibuk dengan aktivitas di luar. Dengan demikian dukungan sosial keluarga sangat berarti bagi individu dalam menghadapi kehidupan di luar dan meringankan stres yang dihadapi individu. Jenis-jenis dukungan keluarga yang didapatkan oleh delapan reponden lansia berpengaruh dalam kemandiriannya yaitu aktivitas atau pekerjaan sehari-hari lansia. Jika keluarga memberikan dukungan yang positif dan maksimal maka dampaknya positif dalam kemandirian lansia.

\section{KESIMPULAN}

Terdapat lima komponen dukungan keluarga, seperti komponen dukungan penghargaan, dukungan nyata, dukungan informasi, dukungan emosional dan dukungan sosial. Terdapat empat tipe kemandirian lansia, yaitu mandiri, ketergantungan ringan, ketergantungan sedang dan ketergantungan total. Komponen dukungan keluarga yang dominan adalah dukungan nyata, dukungan penghargaan dan dukungan emosional. Ditemukan 1 dari 8 responden yang mendapatkan dukungan keluarga secara keseluruhan dan 1 responden mendapatkan 4 komponen dukungan keluarga, sehingga dukungan keluarga yang diterima lansia dapat mempengaruhi kemandiriannya. Dari 8 reponden lansia terdapat 2 orang yang mandiri, lansia yang ketergantungan ringan 4 orang, lansia yang ketergantungan sedang 2 orang dan lansia yang ketergantungan total 1 orang.

\section{DAFTAR PUSTAKA}

Christine, Merlyn. 2010. Hubungan Dukungan Keluarga dengan Respon Cemas Anak Usia Sekolah terhadap Pemasangan Intravena di Rumah Sakit Advent Medan. http: //repository.usu.ac.id/. Tanggal akses 4 November 2016

Friedman. 2002. Buku Ajar Keperawatan Keluarga Riset, Teori, dan Praktek. Edisi kelima, Fakultas Kedokteran Universitas Indonesia. Jakarta.

Indriana, Y. 2012. G erontologi dan Progeria. Pustaka Pelajar. Yogyakarta

Maryam, S., dkk. 2009. Mengenal Usia Lanjut Dan Perawatannya. Salemba Medika. Jakarta

Moloeng, L.J. 2009. Metodologi Penelitian Kualitatif. Remaja Rosdakarya. Bandung

Setiadi. 2008. Konsep \& Keperawatan Keluarga. Yogyakarta : Graha IImu

Tamher, S., dkk. 2009. Kesehatan Usia Lanjut Dengan Pendekatan Asuhan Keperawatan. Salemba

Medika Jakarta 